\title{
New $\mathrm{C}_{19^{-}}$and $\mathrm{C}_{18}$-Diterpenoid Alkaloids from Delphinium anthriscifolium var. savatieri
}

\author{
Lei Song, Xiao-Yu Liu, Qiao-Hong Chen, and Feng-Peng WAnG* \\ Department of Chemistry of Medicinal Natural Products, West China College of Pharmacy, Sichuan University; No. 17, \\ Duan 3, Renmin Nan Road, Chengdu 610041, P. R. China. \\ Received September 8, 2008; accepted October 18, 2008; published online November 12, 2008
}

Three new $\mathrm{C}_{19}$-diterpenoid alkaloids, anthriscifoldines $\mathrm{A}-\mathrm{C}(1-3)$, and two new $\mathrm{C}_{18}$-diterpenoid alkaloids, anthriscifolcines $F$ and $G(5,6)$, were obtained from the whole herbs of Delphinium anthriscifolium var. savatieri during our further investigation on a larger scale of recollected plants. Their structures were elucidated based on the interpretation of NMR and high-resolution ESI-MS data, and chemical transformation. In addition, five known $\mathrm{C}_{19}$-diterpenoid alkaloids were also isolated and identified as nudicaulamine (4), delbruninol (7), blacknine (8), winkleriline (9), and deltaline (10).

Key words Delphinium; anthriscifolium; diterpenoid alkaloid; anthriscifoldine; anthriscifolcine

In a continuation of our phytochemical studies on the pharmacologically interesting plants Aconitum and Delphinium, we obtained a series of structurally and chemotaxonomically interesting diterpenoid alkaloids. ${ }^{1-3)}$ It was very intriguing that we also discovered a novel diterpene from one of these plants. ${ }^{4}$ Delphinium anthriscifolium var. savatieri (Franchet) Munz ${ }^{5)}$ belongs to the Sect. Anthriscifolium (which consists of only 4 plants) of the genus Delphinium. Our earlier chemical investigation of a small batch of specimens of this plant led to the discovery of some new $\mathrm{C}_{18^{-}}$ diterpenoid alkaloids, which presented a chemotaxonomical advantage for the genus Delphinium. ${ }^{6)}$ Further investigation of a large batch of recollected samples resulted in the isolation of three new $\mathrm{C}_{19}$-diterpenoid alkaloids, anthriscifoldines $\mathrm{A}-\mathrm{C}(\mathbf{1}-\mathbf{3})$, and two new $\mathrm{C}_{18}$-diterpenoid alkaloids anthriscifolcines $F$ and $G(\mathbf{5}, \mathbf{6})$, together with five known alkaloids. In this paper, we report the isolation and structural elucidation of these new alkaloids.

\section{Results and Discussion}

Anthriscifoldine A (1) was obtained as a white amorphous powder. Its molecular formula was deduced to be $\mathrm{C}_{25} \mathrm{H}_{37} \mathrm{NO}_{7}$ from a pseudomolecular ion at $m / z 464.2661[\mathrm{M}+\mathrm{H}]^{+}$in its HR-ESI-MS. The ${ }^{1} \mathrm{H}-\mathrm{NMR}$ spectrum (Table 1 ) showed the presence of an $N$-ethyl group $\left(\delta_{\mathrm{H}} 1.06,3 \mathrm{H}, \mathrm{t}, J=7.2 \mathrm{~Hz} ; \delta_{\mathrm{H}}\right.$ $2.90,2 \mathrm{H}, \mathrm{m})$, two methoxy groups $\left(\delta_{\mathrm{H}} 3.34,3.49\right.$, each $3 \mathrm{H}$, $\mathrm{s})$, an acetyl group $\left(\delta_{\mathrm{H}} 2.05,3 \mathrm{H}, \mathrm{s}\right)$, a disubstituted double bond $\left(\delta_{\mathrm{H}} 5.77,1 \mathrm{H}\right.$, dd, $J=9.2,4.8 \mathrm{~Hz} ; \delta_{\mathrm{H}} 5.66,1 \mathrm{H}$, $J=9.6 \mathrm{~Hz}$ ), and a methyl group attached to a quaternary carbon $\left(\delta_{\mathrm{H}} 1.09,3 \mathrm{H}, \mathrm{s}\right)$. The ${ }^{13} \mathrm{C}-\mathrm{NMR}$ and distortionless enhancement by polarization transfer (DEPT) data demonstrated the existence of four methylene carbons $\left(\delta_{\mathrm{C}} 27.5\right.$, $26.7,56.2,50.3)$ and five quaternary carbons $\left(\delta_{\mathrm{C}} 89.1,84.6\right.$, $33.7,49.2,170.1)$. The aforementioned NMR features suggested that compound $\mathbf{1}$ is a lycoctonine-type $\mathrm{C}_{19}$-diterpenoid alkaloid. ${ }^{7)}$ A triplet signal at $\delta_{\mathrm{H}} 4.81(\mathrm{t}, J=4.4 \mathrm{~Hz})$ was attributed to $\mathrm{H}-14 \beta,{ }^{7}$ implying the presence of the only acetoxy group at the $\mathrm{C}-14$ position. The two methoxy groups were attributed to $\mathrm{C}-8$ and $\mathrm{C}-16$ based on the long-range correlations between $8-\mathrm{OCH}_{3}$ and $\mathrm{C}-8$, and $16-\mathrm{OCH}_{3}$ and $\mathrm{C}-16$ in its heteronuclear multiple bonding connectivity (HMBC) spectrum. Along with the above-mentioned signals, its ${ }^{13} \mathrm{C}-\mathrm{NMR}$ spectrum (Table 2) displayed six oxygenated carbon signals, suggesting that this compound possesses three additional hy-
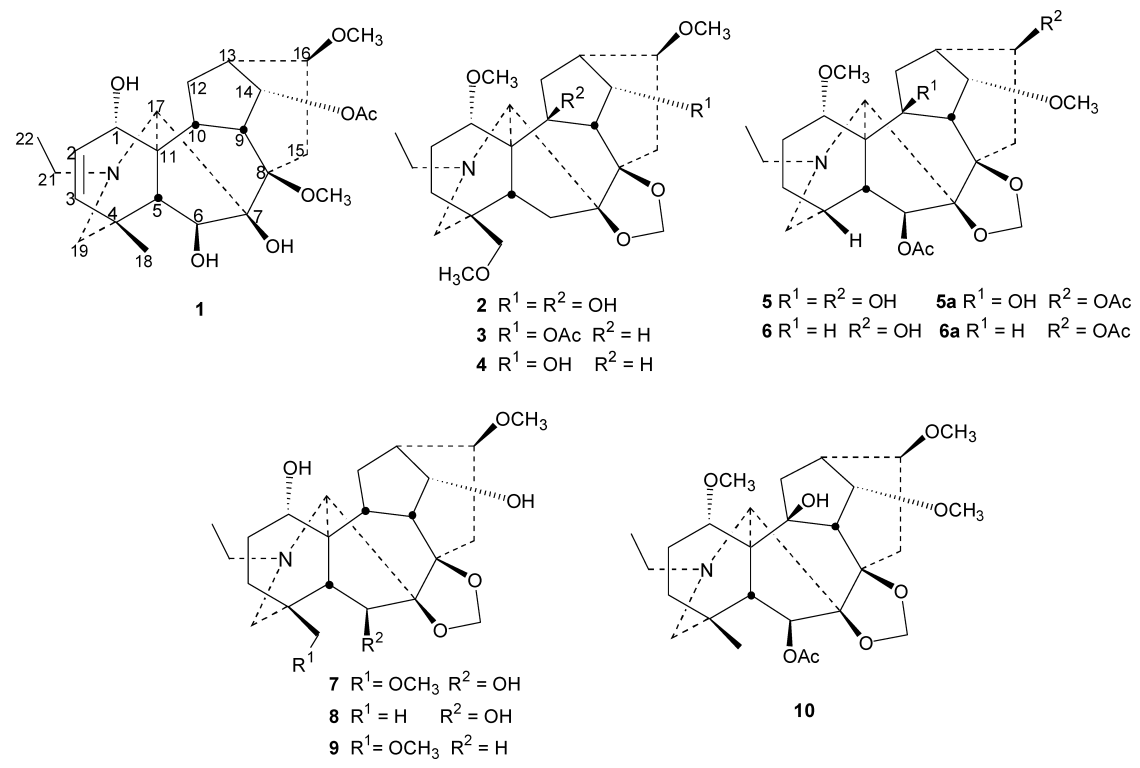

* To whom correspondence should be addressed. e-mail: wfp@scu.edu.cn 
Table 1. ${ }^{1} \mathrm{H}-\mathrm{NMR}$ Data for Compounds 1, 2,5 and $6\left(400 \mathrm{MHz}, \delta_{\mathrm{H}}\right.$ Mult., $J=\mathrm{Hz}$ in $\left.\mathrm{CDCl}_{3}\right)$

\begin{tabular}{|c|c|c|c|c|}
\hline Position & 1 & 2 & 5 & 6 \\
\hline 1 & $3.72 \mathrm{~d}(4.4)$ & $3.63 \mathrm{dd}(10.4,7.2)$ & $3.58 \mathrm{t}(8.4)$ & $3.03 \mathrm{dd}(10.4,7.2)$ \\
\hline 2 & $5.77 \mathrm{dd}(9.2,4.8)$ & $2.07 \mathrm{~m}$ & $\begin{array}{l}2.80 \mathrm{~m}(\beta) \\
2.08 \mathrm{~m}(\alpha)\end{array}$ & 2.01 overlapped \\
\hline 3 & $5.66 \mathrm{~d}(9.6)$ & $1.44 \mathrm{~m}$ & $1.35 \mathrm{~m}$ & 1.78 overlapped \\
\hline 4 & - & - & 2.11 overlapped & $2.16 \mathrm{~m}$ \\
\hline 5 & $1.65 \mathrm{~s}$ & $1.78 \mathrm{~m}$ & $1.86 \mathrm{~m}$ & $1.53 \mathrm{~m}$ \\
\hline 6 & $4.28 \mathrm{~s}$ & 2.18 overlapped & $5.32 \mathrm{~s}$ & $5.23 \mathrm{~s}$ \\
\hline 9 & $2.17 \mathrm{~m}$ & 2.30 overlapped & $3.49 \mathrm{~m}$ & $3.62 \mathrm{t}(5.2)$ \\
\hline 10 & $2.56 \mathrm{~m}$ & - & - & 1.87 overlapped \\
\hline \multirow[t]{2}{*}{12} & $2.28 \mathrm{~m}$ & 2.41 overlapped & $2.63 \mathrm{~m}$ & 2.10 overlapped \\
\hline & $2.24 \mathrm{~m}$ & $1.70 \mathrm{~m}$ & $1.68 \mathrm{~m}$ & $1.93 \mathrm{~m}$ \\
\hline 13 & $3.26 \mathrm{~m}$ & $2.55 \mathrm{~m}$ & $2.50 \mathrm{~m}$ & $2.37 \mathrm{~m}$ \\
\hline 14 & $4.81 \mathrm{t}(4.4)$ & $4.63 \mathrm{q}(5.6)$ & $4.30 \mathrm{t}(4.4)$ & $3.79 \mathrm{t}(4.8)$ \\
\hline \multirow[t]{2}{*}{15} & $2.58 \mathrm{~m}(\beta)$ & $1.79 \mathrm{~m}(\beta)$ & $2.59 \mathrm{~m}(\beta)$ & $2.57 \mathrm{~m}(\beta)$ \\
\hline & $1.88 \mathrm{~m}(\alpha)$ & $1.77 \mathrm{~m}(\alpha)$ & $1.75 \mathrm{~m}(\alpha)$ & $1.73 \mathrm{~m}(\alpha)$ \\
\hline 16 & $3.38 \mathrm{~d}(5.2)$ & 3.46 br d (7.6) & $3.66 \mathrm{~m}$ & $3.70 \mathrm{t}(10.0)$ \\
\hline 17 & $2.78 \mathrm{brs}$ & $3.18 \mathrm{~s}$ & $3.28 \mathrm{br} \mathrm{s}$ & $3.39 \mathrm{brs}$ \\
\hline 18 & $1.09 \mathrm{~s}$ & $3.13,3.01 \mathrm{ABq}(8.8)$ & & \\
\hline \multirow[t]{2}{*}{19} & $2.43 \mathrm{~m}$ & $2.66 \mathrm{~m}$ & $2.88 \mathrm{~m}$ & $2.85 \mathrm{~m}$ \\
\hline & & $2.44 \mathrm{~m}$ & & \\
\hline \multirow[t]{2}{*}{21} & $2.90 \mathrm{~m}$ & $2.83 \mathrm{~m}$ & $2.77 \mathrm{~m}$ & $2.77 \mathrm{~m}$ \\
\hline & & $2.73 \mathrm{~m}$ & & \\
\hline 22 & $1.06 \mathrm{t}(7.2)$ & $1.06 \mathrm{t}(7.2)$ & $1.07 \mathrm{t}(7.2)$ & $1.06 \mathrm{t}(7.2)$ \\
\hline $1-\mathrm{OCH}_{3}$ & & $3.26 \mathrm{~s}$ & $3.26 \mathrm{~s}$ & $3.26 \mathrm{~s}$ \\
\hline $8-\mathrm{OCH}_{3}$ & $3.49 \mathrm{~s}$ & & & \\
\hline $14-\mathrm{OCH}_{3}$ & & & $3.51 \mathrm{~s}$ & $3.51 \mathrm{~s}$ \\
\hline $16-\mathrm{OCH}_{3}$ & $3.34 \mathrm{~s}$ & $3.30 \mathrm{~s}$ & & \\
\hline $18-\mathrm{OCH}_{3}$ & & $3.35 \mathrm{~s}$ & & \\
\hline $\mathrm{OCH}_{2} \mathrm{O}$ & & $5.05 \mathrm{~s}, 4.97 \mathrm{~s}$ & $4.97 \mathrm{~s}, 4.94 \mathrm{~s}$ & $4.97 \mathrm{~s}, 4.96 \mathrm{~s}$ \\
\hline $\mathrm{OAc}$ & $2.05 \mathrm{~s}$ & & $2.08 \mathrm{~s}$ & $2.07 \mathrm{~s}$ \\
\hline
\end{tabular}

droxyl groups in addition to an ester group and two methoxy groups. The one-proton doublet signal at $\delta_{\mathrm{H}} 3.72(J=4.4 \mathrm{~Hz})$ in the ${ }^{1} \mathrm{H}-\mathrm{NMR}$ spectrum was assigned to $\mathrm{H}-1 \beta$, and the singlet at $\delta_{\mathrm{H}} 4.28$ to $\mathrm{H}-6 \alpha$. In addition, the location of the three hydroxyl groups at C-1, C-6, and C-7 was further confirmed by the corresponding correlation spectroscopy (COSY) and HMBC correlations (Fig. 1). Also, the presence of a $\Delta^{2,3}$ double bond could be corroborated by the critical HMBC correlations (Fig. 1) from $\mathrm{H}-2\left(\delta_{\mathrm{H}} 5.77\right)$ to $\mathrm{C}-4$ and $\mathrm{C}-11$, and from $\mathrm{H}-3\left(\delta_{\mathrm{H}} 5.66\right)$ to $\mathrm{C}-5, \mathrm{C}-18$, and $\mathrm{C}-19$. The structure of anthriscifoldine A was thus established.

Anthriscifoldine B (2) has the molecular formula as $\mathrm{C}_{25} \mathrm{H}_{39} \mathrm{NO}_{7}$, which was determined by HR-ESI-MS $(\mathrm{m} / \mathrm{z}$ 466.2801 $[\mathrm{M}+\mathrm{H}]^{+}$). Compound 2 also exhibited characteristic NMR features (Tables 1, 2) of a lycoctonine-type $\mathrm{C}_{19^{-}}$ diterpenoid alkaloid $\left.{ }^{7}\right)$ bearing an $N$-ethyl group $\left(\delta_{\mathrm{H}} 1.06,3 \mathrm{H}\right.$, $\mathrm{t}, J=7.2 \mathrm{~Hz} ; \delta_{\mathrm{H}} 2.73,2.83$, each $\left.1 \mathrm{H}, \mathrm{m} ; \delta_{\mathrm{C}} 14.0 \mathrm{q}, 50.6 \mathrm{t}\right)$, three methoxy groups $\left(\delta_{\mathrm{H}} 3.26,3.30,3.35\right.$, each $3 \mathrm{H}, \mathrm{s} ; \delta_{\mathrm{C}}$ $55.7 \mathrm{q}, 59.5 \mathrm{q}, 56.4 \mathrm{q})$, and a methylenedioxy group $\left(\delta_{\mathrm{H}}\right.$ $4.97,5.05$, each $\left.1 \mathrm{H}, \mathrm{s} ; \delta_{\mathrm{C}} 93.8 \mathrm{t}\right)$, as well as five quaternary carbons at $\delta_{\mathrm{C}} 38.2,55.7,78.1,82.6$, and 91.7. The three methoxy groups could be readily assigned to $\mathrm{C}-1, \mathrm{C}-16$, and $\mathrm{C}-18$ based on the cross-peaks (between $1-\mathrm{OCH}_{3}$ and $\mathrm{C}-1$, $16-\mathrm{OCH}_{3}$ and $\mathrm{C}-16$, and $18-\mathrm{OCH}_{3}$ and $\left.\mathrm{C}-18\right)$ observed in its HMBC spectrum (Fig. 1). The methylenedioxy was located at $\mathrm{C}-7$ and $\mathrm{C}-8$ due to the long-range correlations of the methylene group with $\mathrm{C}-7$ and $\mathrm{C}-8$. The existence of seven oxygenated carbons deduced from its ${ }^{13} \mathrm{C}-\mathrm{NMR}$ spectrum suggested that $\mathbf{2}$ had two hydroxyl groups in addition to three methoxy groups and a methylenedioxy group. The $\mathrm{H}-14 \beta$
Table 2. ${ }^{13} \mathrm{C}-\mathrm{NMR}$ Data for Compounds $\mathbf{1}-\mathbf{3}, \mathbf{5}$, and $\mathbf{6}\left(100 \mathrm{MHz}, \mathrm{CDCl}_{3}\right)$

\begin{tabular}{|c|c|c|c|c|c|}
\hline Position & 1 & 2 & 3 & 5 & 6 \\
\hline 1 & $70.9 \mathrm{~d}$ & $77.9 \mathrm{~d}$ & $83.7 \mathrm{~d}$ & $77.1 \mathrm{~d}$ & $83.8 \mathrm{~d}$ \\
\hline 2 & $130.1 \mathrm{~d}$ & $26.0 \mathrm{t}$ & $26.5 \mathrm{t}$ & $25.9 \mathrm{t}$ & $25.8 \mathrm{t}$ \\
\hline 3 & $137.4 \mathrm{~d}$ & $32.1 \mathrm{t}$ & $32.3 \mathrm{t}$ & $28.6 \mathrm{t}$ & $28.9 \mathrm{t}$ \\
\hline 4 & $33.7 \mathrm{~s}$ & $38.2 \mathrm{~s}$ & $38.1 \mathrm{~s}$ & $33.7 \mathrm{~d}$ & $33.9 \mathrm{~d}$ \\
\hline 5 & $57.5 \mathrm{~d}$ & $39.3 \mathrm{~d}$ & $43.3 \mathrm{~d}$ & $44.5 \mathrm{~d}$ & $49.6 \mathrm{~d}$ \\
\hline 6 & $81.7 \mathrm{~d}$ & $32.3 \mathrm{t}$ & $32.0 \mathrm{t}$ & $81.4 \mathrm{~d}$ & $80.8 \mathrm{~d}$ \\
\hline 7 & $89.1 \mathrm{~s}$ & $91.7 \mathrm{~s}$ & $90.8 \mathrm{~s}$ & $92.8 \mathrm{~s}$ & $93.6 \mathrm{~s}$ \\
\hline 8 & $84.6 \mathrm{~s}$ & $82.6 \mathrm{~s}$ & $81.3 \mathrm{~s}$ & $80.4 \mathrm{~s}$ & $81.6 \mathrm{~s}$ \\
\hline 9 & $44.5 \mathrm{~d}$ & $55.4 \mathrm{~d}$ & $47.0 \mathrm{~d}$ & $47.9 \mathrm{~d}$ & $38.6 \mathrm{~d}$ \\
\hline 10 & $37.0 \mathrm{~d}$ & $78.1 \mathrm{~s}$ & $36.5 \mathrm{~d}$ & $83.1 \mathrm{~s}$ & $47.9 \mathrm{~d}$ \\
\hline 11 & $49.2 \mathrm{~s}$ & $55.7 \mathrm{~s}$ & $50.7 \mathrm{~s}$ & $54.6 \mathrm{~s}$ & $49.3 \mathrm{~s}$ \\
\hline 12 & $27.5 \mathrm{t}$ & $36.9 \mathrm{t}$ & $27.3 \mathrm{t}$ & $37.8 \mathrm{t}$ & $27.1 \mathrm{t}$ \\
\hline 13 & $42.1 \mathrm{~d}$ & $36.3 \mathrm{~d}$ & $44.2 \mathrm{~d}$ & $40.1 \mathrm{~d}$ & $40.1 \mathrm{~d}$ \\
\hline 14 & $75.4 \mathrm{~d}$ & $72.8 \mathrm{~d}$ & $75.2 \mathrm{~d}$ & $82.4 \mathrm{~d}$ & $83.7 \mathrm{~d}$ \\
\hline 15 & $26.7 \mathrm{t}$ & $32.8 \mathrm{t}$ & $33.5 \mathrm{t}$ & $37.8 \mathrm{t}$ & $37.0 \mathrm{t}$ \\
\hline 16 & $82.4 \mathrm{~d}$ & $81.1 \mathrm{~d}$ & $81.3 \mathrm{~d}$ & $71.7 \mathrm{~d}$ & $72.1 \mathrm{~d}$ \\
\hline 17 & $65.0 \mathrm{~d}$ & $62.6 \mathrm{~d}$ & $62.1 \mathrm{~d}$ & $64.7 \mathrm{~d}$ & $64.8 \mathrm{~d}$ \\
\hline 18 & $23.7 \mathrm{q}$ & $78.8 \mathrm{t}$ & $78.9 \mathrm{t}$ & & \\
\hline 19 & $56.2 \mathrm{t}$ & $52.3 \mathrm{t}$ & $52.4 \mathrm{t}$ & $50.6 \mathrm{t}$ & $50.7 \mathrm{t}$ \\
\hline 21 & $50.3 \mathrm{t}$ & $50.6 \mathrm{t}$ & $50.7 \mathrm{t}$ & $50.3 \mathrm{t}$ & $50.6 \mathrm{t}$ \\
\hline 22 & $13.7 \mathrm{q}$ & $14.0 \mathrm{q}$ & $14.0 \mathrm{q}$ & $13.9 \mathrm{q}$ & $13.9 \mathrm{q}$ \\
\hline $1-\mathrm{OCH}_{3}$ & & $55.7 \mathrm{q}$ & $55.8 \mathrm{q}$ & $55.7 \mathrm{q}$ & $55.9 \mathrm{q}$ \\
\hline $8-\mathrm{OCH}_{3}$ & $57.6 \mathrm{q}$ & & & & \\
\hline $14-\mathrm{OCH}_{3}$ & & & & $58.0 \mathrm{q}$ & $57.9 \mathrm{q}$ \\
\hline $16-\mathrm{OCH}_{3}$ & $56.2 \mathrm{q}$ & $56.4 \mathrm{q}$ & $56.2 \mathrm{q}$ & & \\
\hline $18-\mathrm{OCH}_{3}$ & & $59.5 \mathrm{q}$ & $59.5 \mathrm{q}$ & & \\
\hline $\mathrm{OCH}_{2} \mathrm{O}$ & & $93.8 \mathrm{t}$ & $93.3 \mathrm{t}$ & $93.9 \mathrm{t}$ & $93.7 \mathrm{t}$ \\
\hline \multirow[t]{2}{*}{$\mathrm{OAc}$} & $170.1 \mathrm{~s}$ & & $171.7 \mathrm{~s}$ & $170.2 \mathrm{~s}$ & $170.3 \mathrm{~s}$ \\
\hline & $21.1 \mathrm{q}$ & & $21.4 \mathrm{q}$ & $21.7 \mathrm{q}$ & $21.6 \mathrm{q}$ \\
\hline
\end{tabular}



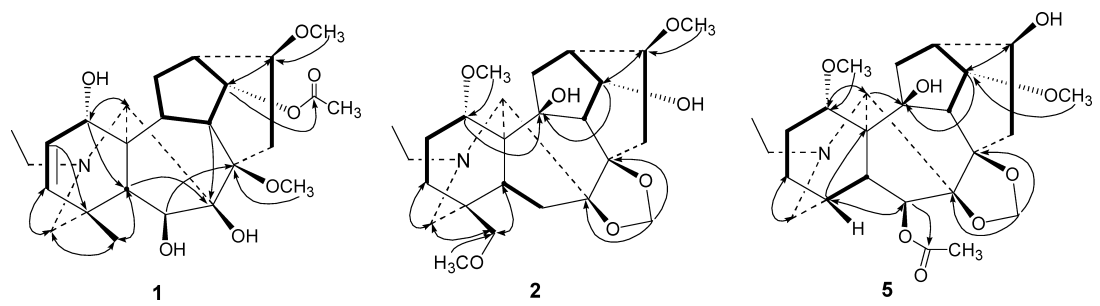

Fig. 1. Key ${ }^{1} \mathrm{H}-{ }^{1} \mathrm{H}$ COSY Correlations $(-)$ and Selected HMBC Correlations $(\mathrm{H} \frown \mathrm{C})$ of $\mathbf{1}, \mathbf{2}$ and $\mathbf{5}$

signal appeared at a lower field [ $\left.\delta_{\mathrm{H}} 4.63(\mathrm{q}, J=5.6 \mathrm{~Hz})\right]$, indicating the location of the two hydroxyl groups at $\mathrm{C}-10$ and $\mathrm{C}-14$, which was supported by the key correlations in its HMBC spectrum (Fig. 1). Notably, the chemical shift value of $\mathrm{C}-1$ and $\mathrm{C}-14$ appeared at a higher field due to the $\gamma$ gauch effect of a $10-\mathrm{OH}$ group. All available evidence indicated the structure of anthriscifoldine B to be 2 .

Anthriscifoldine $\mathrm{C}(\mathbf{3})$, a white amorphous powder, $\mathrm{C}_{27} \mathrm{H}_{41} \mathrm{NO}_{7}$ (HR-ESI-MS), was also a lycoctonine-type $\mathrm{C}_{19^{-}}$ diterpenoid alkaloid. ${ }^{7)}$ Its NMR data showed distinctive signals at $\delta_{\mathrm{H}} 1.06(3 \mathrm{H}, \mathrm{t}, J=7.2 \mathrm{~Hz})$ and $\delta_{\mathrm{C}} 14.0 \mathrm{q}$ for an $N$ ethyl group; $\delta_{\mathrm{H}} 3.26,3.28,3.29$ (each $3 \mathrm{H}, \mathrm{s}$ ) for three methoxy groups; $\delta_{\mathrm{H}} 4.93,5.01($ each $1 \mathrm{H}, \mathrm{s})$ and $\delta_{\mathrm{C}} 93.3 \mathrm{t}$ for a methylenedioxy group; and $\delta_{\mathrm{H}} 2.07(3 \mathrm{H}, \mathrm{s})$ with $\delta_{\mathrm{C}} 21.4 \mathrm{q}$, $171.7 \mathrm{~s}$ for an acetoxy group. Comparison of the NMR data of 3 with those of the known nudicaulamine ${ }^{8)}$ (4) revealed that they were structurally similar except for the existence of an additional acetyl group in 3. Notably, the H-14 $\beta$ signal in 3 appeared at $\delta_{\mathrm{H}} 4.82(\mathrm{t}, J=4.8 \mathrm{~Hz})$ instead of at $\delta_{\mathrm{H}} 4.04(\mathrm{t}$, $J=4.8 \mathrm{~Hz}$ ) in 4 . The acetyl group was therefore attached to $\mathrm{C}-14$ in 3. This assignment was further supported by hydrolysis of 3 with $5 \% \mathrm{NaOH} / \mathrm{CH}_{3} \mathrm{OH}$ to yield a product that was identical to an authentic sample of 4.

Anthriscifolcine F (5) was obtained as a white amorphous powder, and its molecular formula $\mathrm{C}_{25} \mathrm{H}_{37} \mathrm{NO}_{8}$ was determined based on a pseudomolecular ion peak at $\mathrm{m} / \mathrm{z} 480.2573$ $[\mathrm{M}+\mathrm{H}]^{+}$in its HR-ESI-MS spectrum. The NMR spectra (Tables 1,2$)$ indicated the presence of an $N$-ethyl group $\left(\delta_{\mathrm{H}}\right.$ $1.07,3 \mathrm{H}, \mathrm{t}, J=7.2 \mathrm{~Hz} ; \delta_{\mathrm{H}} 2.77,2 \mathrm{H}, \mathrm{m} ; \delta_{\mathrm{C}} 13.9 \mathrm{q}, 50.3 \mathrm{t}$ ), two methoxy groups $\left(\delta_{\mathrm{H}} 3.26,3.51\right.$, each $3 \mathrm{H}, \mathrm{s} ; \delta_{\mathrm{C}} 55.7 \mathrm{q}, 58.0$ $\mathrm{q})$, an acetoxy group $\left(\delta_{\mathrm{H}} 2.08,3 \mathrm{H}, \mathrm{s} ; \delta_{\mathrm{C}} 170.2 \mathrm{~s}, 21.7 \mathrm{q}\right)$, and a methylenedioxy group $\left(\delta_{\mathrm{H}} 4.94,4.97\right.$, each $1 \mathrm{H}, \mathrm{s} ; \delta_{\mathrm{C}} 93.9$ $\mathrm{t})$, as well as five quaternary carbons $\left(\delta_{\mathrm{C}} 54.6,80.4,83.1\right.$, $92.8,170.2)$. The presence of only one nonoxygenated quaternary carbon at $\delta_{\mathrm{C}} 54.6$ suggested that compound $\mathbf{5}$ is a $\mathrm{C}_{18^{-}}$ diterpenoid alkaloid. ${ }^{9)}$ The key HMBC correlations (Fig. 1) of $\mathrm{H}-1 \beta\left(\delta_{\mathrm{H}} 3.58, \mathrm{t}, J=8.4 \mathrm{~Hz}\right)$ with $1-\mathrm{OCH}_{3}$, and of $\mathrm{H}-14 \beta$ $\left(\delta_{\mathrm{H}} 4.30, \mathrm{t}, J=4.4 \mathrm{~Hz}\right)$ with $14-\mathrm{OCH}_{3}$ confirmed the attachment of two methoxy groups at $\mathrm{C}-1$ and $\mathrm{C}-14$. The HMBC cross-peak between $\mathrm{H}-6\left(\delta_{\mathrm{H}} 5.32, \mathrm{~s}\right)$ and the carbonyl carbon of OAc indicated the location of the acetoxy group at C- 6 . The methylenedioxy group was located at C-7 and C-8 based on the long-range correlations of the methylene group with $\mathrm{C}-7$ and C-8. Along with the above-mentioned signals, its ${ }^{13} \mathrm{C}-\mathrm{NMR}$ spectrum displayed seven oxygenated carbon signals, suggesting that this compound possesses two additional hydroxyl groups, which could be located at $\mathrm{C}-10$ and $\mathrm{C}-16$ due to the HMBC correlations shown in Fig. 1. The above findings led to the assignment of anthriscifolcine $\mathrm{F}$ as $\mathbf{5}$.

The molecular formula of anthriscifolcine $G(6)$ was de-

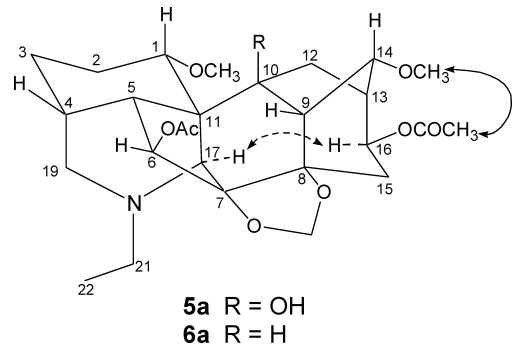

Fig. 2. Key NOE Correlations $(\mathrm{H} \asymp \mathrm{H})$ of $\mathbf{5 a}$ and $\mathbf{6 a}$

duced to be $\mathrm{C}_{25} \mathrm{H}_{37} \mathrm{NO}_{7}$ from its HR-ESI-MS at $m / z 464.2650$ $[\mathrm{M}+\mathrm{H}]^{+}$. From its NMR data (Tables 1,2 ), an $N$-ethyl group, two methoxy groups, an acetoxy group, and a methylenedioxy group could be easily recognized. Compound 6 shared highly similar ${ }^{1} \mathrm{H}$ - and ${ }^{13} \mathrm{C}-\mathrm{NMR}$ spectral patterns with those of $\mathbf{5}$. The only difference is that the C-10 oxygenated quaternary carbon $\left(\delta_{\mathrm{C}} 83.1 \mathrm{~s}\right)$ in $\mathbf{5}$ was replaced with a methine carbon $\left(\delta_{\mathrm{C}} 47.9 \mathrm{~d}\right)$ in $\mathbf{6}$. The structure of anthriscifolcine $\mathrm{G}$ was further confirmed by extensive analyses of its 1D NMR and 2D NMR spectra.

The configurations at C- 6 and $\mathrm{C}-16$ in all new alkaloids were determined based on NMR data and selective NOE difference spectra. As mentioned in our previous report, ${ }^{6}$ the configuration of 6-OH in $\mathbf{1}$ or 6-OAc in 5 and $\mathbf{6}$ has a $\beta$-orientation due to the singlet signal corresponding to $\mathrm{H}-6 \alpha$ in their ${ }^{1} \mathrm{H}-\mathrm{NMR}$ spectra. ${ }^{7}$ ) The configuration of $16-\mathrm{OCH}_{3}$ in compounds $\mathbf{1}-\mathbf{3}$ was also determined to have a $\beta$-orientation according to the $\delta$ values $(81-83 \mathrm{ppm})$ of $\mathrm{C}-16$ in their ${ }^{13} \mathrm{C}$ NMR spectra. ${ }^{10)}$

The orientation of the 16-OH group in $\mathbf{5}$ and $\mathbf{6}$ was ambiguous at first since no evident NOE correlation could be found when H-16 was irradiated. Fortunately, from the derivatives $(\mathbf{5 a}, \mathbf{6 a})$ prepared by acetylation of $16-\mathrm{OH}$ in compounds 5 and 6, NOE correlations (Fig. 2) could be observed between 16-OAc and $14-\mathrm{OCH}_{3}$, and $\mathrm{H}-16$ and $\mathrm{H}-17$ in both 5a and 6a. The configuration of the 16-OH group in 5 and $\mathbf{6}$ therefore was unambiguously established to have a $\beta$-orientation. The conformation of the D ring in $\mathbf{5 a}$ and $\mathbf{6 a}$ was suggested to be a boat one, which would enable the 16-OAc substituent to remain in an equatorial position.

The five known $\mathrm{C}_{19}$-diterpenoid alkaloids isolated from this plant were identified as nudicaulamine $(4),{ }^{8)}$ delbruninol (7), ${ }^{11)}$ blacknine $(\mathbf{8}),{ }^{12}$ winkleriline $(9),{ }^{13)}$ and deltaline $(\mathbf{1 0})^{10)}$ by comparing their spectroscopic data with those reported in the literature. The abundant chemical components found in this plant should be very helpful in further chemotaxonomic research on the Delphinium genus. 


\section{Experimental}

General Experimental Procedures Optical rotations were measured on a Perkin-Elmer 341 polarimeter. IR spectra were obtained on a Nicolet FTIR 200 SXV spectrophotometer. NMR spectra were recorded on a Varian Unity INOVA 400/45 NMR spectrometer. Mass spectra were carried out on Finnigan LCQ and Micromass Auto Ultima-Tof spectrometers. Silica gel H (Qindao Sea Chemical Factory, P. R. China) was used for column chromatography. Spots on TLC plates (silica gel G, Qindao Sea Chemical Factory) were visualized with modified Dragendorff's reagent

Plant Material D. anthriscifolium var. savatieri was collected from Pengzhou, Sichuan Province, P. R. China, in June 2006 and authenticated by Wen-Jin Zhang of Pengzhou County Centre of Disease Prevention and Control. A voucher specimen (No. 20060918-1) was deposited in the West China College of Pharmacy, Sichuan University.

Extraction and Isolation The dried and powdered whole herbs $(4.0 \mathrm{~kg})$ of $D$. anthriscifolium var. savatieri were percolated with $0.1 \mathrm{~mol} / 1 \mathrm{HCl}(401)$. The filtrate was then alkalized with $25 \%$ aqueous $\mathrm{NH}_{4} \mathrm{OH}(1.51)$ to $\mathrm{pH}>9$ and extracted with ethyl acetate $(201 \times 3)$. Removal of the solvent under reduced pressure gave a residue of $10.0 \mathrm{~g}$. Four extractions in total were performed in the same procedure to produce $42.5 \mathrm{~g}$ of crude alkaloids, which were then subjected to silica gel column chromatography eluted with chloroform-methanol $(100: 1 \rightarrow 95: 5)$ to give 10 fractions $(A-J)$. Fraction B $(1.1 \mathrm{~g})$ was further chromatographed on a silica gel column eluted with chloroform-methanol $(400: 1)$ to give four subfractions. Compound $3(5 \mathrm{mg})$ was obtained by purification of subfraction B- $4(79 \mathrm{mg})$ on a silica gel column using cyclohexane-ethyl acetate $(10: 1)$ as the eluent. Fraction $\mathrm{C}(1.9 \mathrm{~g})$ was subjected to silica gel column chromatography eluted with cyclohexane-ethyl acetate $(15: 1)$ to give $\mathbf{6}(15 \mathrm{mg})$. Fraction E $(2.0 \mathrm{~g})$ was chromatographed on a silica gel column and eluted with cyclohexane-acetone $(10: 1)$ to yield three subfractions (E-1-E-3). E-2 was further chromatographed on a silica gel column eluted with chloroform-methanol $(400: 1)$ to provide compound $1(47 \mathrm{mg})$ and nudicaulamine $(4,15 \mathrm{mg})$. E-3 was subjected to silica gel column chromatography eluted with cyclohexane-acetone $(10: 1)$ to give deltaline $(\mathbf{1 0}, 5 \mathrm{mg})$. Fraction $\mathrm{G}(1.2 \mathrm{~g})$ was chromatographed on a silica gel column using cyclohexane-acetone $(8: 1)$ as the eluent to give three subfractions. Subfraction G-1 was purified on a silica gel column eluted with chloroform-methanol $(300: 1)$ to afford compound $5(52 \mathrm{mg})$. Chromatography of fraction $\mathrm{H}(5.5 \mathrm{~g})$ on a silica gel column eluted with cyclohexane-acetone $(8: 1)$ produced six subfractions $(\mathrm{H}-$ 1-H-6). Delbruninol (7, $19 \mathrm{mg}$ ) was recrystallized from fraction H-4 with acetone. Winkleriline $(9,23 \mathrm{mg})$ and blacknine $(8,30 \mathrm{mg})$ were obtained from column chromatography of H-5 using chloroform-methanol $(200: 1)$ as the eluent. Fraction H-6 (180 mg) was further purified on a silica gel column using cyclohexane-acetone $(10: 1)$ as the eluent to yield compound 2 (10 mg).

Anthriscifoldine A (1): White amorphous powder; $[\alpha]_{\mathrm{D}}^{20}+66.7^{\circ}(c=0.50$ $\mathrm{CHCl}_{3}$ ); IR ( $\left.\mathrm{KBr}\right) \mathrm{cm}^{-1}: 3488,3477,1738 ;{ }^{1} \mathrm{H}-\mathrm{NMR}\left(400 \mathrm{MHz}, \mathrm{CDCl}_{3}\right)$, see Table $1 ;{ }^{13} \mathrm{C}$-NMR $\left(100 \mathrm{MHz}, \mathrm{CDCl}_{3}\right)$, see Table 2; HR-ESI-MS $\mathrm{m} / \mathrm{z}$ : 464.2661 [M+H] $]^{+}$, Calcd for $\mathrm{C}_{25} \mathrm{H}_{38} \mathrm{NO}_{7}, 464.2643$.

Anthriscifoldine B (2): White amorphous powder; $[\alpha]_{\mathrm{D}}^{20}-22.5^{\circ}(c=0.40$, $\mathrm{CHCl}_{3}$ ); IR ( $\left.\mathrm{KBr}\right) \mathrm{cm}^{-1}: 3430,2929,1090 ;{ }^{1} \mathrm{H}-\mathrm{NMR}\left(400 \mathrm{MHz}, \mathrm{CDCl}_{3}\right)$, see Table $1 ;{ }^{13} \mathrm{C}$-NMR $\left(100 \mathrm{MHz}, \mathrm{CDCl}_{3}\right)$, see Table 2; HR-ESI-MS $\mathrm{m} / \mathrm{z}$ : $466.2801[\mathrm{M}+\mathrm{H}]^{+}$, Calcd for $\mathrm{C}_{25} \mathrm{H}_{40} \mathrm{NO}_{7}, 466.2805$.

Anthriscifoldine $\mathrm{C}(\mathbf{3})$ : White amorphous powder; $[\alpha]_{\mathrm{D}}^{20}-15.4^{\circ}(c=0.18$, $\left.\mathrm{CH}_{3} \mathrm{COCH}_{3}\right)$; IR $(\mathrm{KBr}) \mathrm{cm}^{-1}: 3384,2876,1735,1245,1087 ;{ }^{1} \mathrm{H}-\mathrm{NMR}$ $\left(400 \mathrm{MHz}, \mathrm{CDCl}_{3}\right) \delta_{\mathrm{H}} 1.06(3 \mathrm{H}, \mathrm{t}, J=7.2 \mathrm{~Hz}, \mathrm{H}-22), 2.07(3 \mathrm{H}, \mathrm{s}, \mathrm{OAc})$, $3.10,3.01$ (ABq, $J=8.8 \mathrm{~Hz}, \mathrm{H}-18$ ), 3.26, 3.28, 3.29 (each $3 \mathrm{H}, \mathrm{s}, 3 \times \mathrm{OCH}_{3}$ ), $4.82(1 \mathrm{H}, \mathrm{t}, J=4.8 \mathrm{~Hz}, \mathrm{H}-14 \beta), 5.01,4.93\left(\right.$ each $\left.1 \mathrm{H}, \mathrm{s}, \mathrm{OCH}_{2} \mathrm{O}\right) ;{ }^{13} \mathrm{C}-\mathrm{NMR}$ $\left(100 \mathrm{MHz}, \mathrm{CDCl}_{3}\right)$, see Table 2; HR-ESI-MS $m / z 492.2940[\mathrm{M}+\mathrm{H}]^{+}$, Calcd for $\mathrm{C}_{27} \mathrm{H}_{42} \mathrm{NO}_{7}, 492.2961$.
Hydrolysis of Anthriscifoldine C (3): A solution of anthriscifoldine C (3) $(5 \mathrm{mg})$ in $2 \mathrm{ml}$ of $5 \% \mathrm{NaOH} / \mathrm{CH}_{3} \mathrm{OH}$ was stirred at room temperature for $1 \mathrm{~h}$. The reaction mixture was extracted with $\mathrm{CHCl}_{3}$, the combined extracts were dried over anhydrous $\mathrm{Na}_{2} \mathrm{SO}_{4}$, and the solvent was removed to yield the corresponding hydrolytic derivative nudicaulamine $(4)(2 \mathrm{mg})$.

Anthriscifolcine F (5): White amorphous powder; $[\alpha]_{\mathrm{D}}^{20}-27.8^{\circ}(c=0.50$, $\mathrm{CHCl}_{3}$ ); IR ( $\left.\mathrm{KBr}\right) \mathrm{cm}^{-1}: 3421,1736,1090 ;{ }^{1} \mathrm{H}-\mathrm{NMR}\left(400 \mathrm{MHz}, \mathrm{CDCl}_{3}\right.$ ), see Table $1 ;{ }^{13} \mathrm{C}$-NMR $\left(100 \mathrm{MHz}, \mathrm{CDCl}_{3}\right)$, see Table 2; HR-ESI-MS $\mathrm{m} / \mathrm{z}$ : $480.2573[\mathrm{M}+\mathrm{H}]^{+}$, Calcd for $\mathrm{C}_{25} \mathrm{H}_{38} \mathrm{NO}_{8}, 480.2592$.

Acetylation of Anthriscifolcine F (5): $1 \mathrm{ml}$ of acetic anhydride was added to a solution of anthriscifolcine $F(\mathbf{5})(30 \mathrm{mg})$ in pyridine $(3 \mathrm{ml})$, and the mixture was stirred at room temperature for $4 \mathrm{~h}$. Then $\mathbf{5 a}(25 \mathrm{mg})$ was obtained after the usual work-up and flash column chromatography. 5a: white amorphous powder; $[\alpha]_{\mathrm{D}}^{20}-20.6^{\circ}\left(c=0.50, \mathrm{CHCl}_{3}\right) ;{ }^{1} \mathrm{H}-\mathrm{NMR}(400 \mathrm{MHz}$, $\left.\mathrm{CDCl}_{3}\right) \delta_{\mathrm{H}} 1.07(3 \mathrm{H}, \mathrm{t}, J=7.2 \mathrm{~Hz}, \mathrm{H}-22), 2.04,2.08$ (each $3 \mathrm{H}, \mathrm{s}, 2 \times \mathrm{OAc}$ ), $3.15(1 \mathrm{H}, \mathrm{s}, \mathrm{H}-17), 3.26,3.51\left(\mathrm{each} 3 \mathrm{H}, \mathrm{s}, 2 \times \mathrm{OCH}_{3}\right), 4.15(1 \mathrm{H}, \mathrm{t}, J=4.8 \mathrm{~Hz}$, $\mathrm{H}-14 \beta), 4.72(1 \mathrm{H}, \mathrm{dd}, J=8.8,6.8 \mathrm{~Hz}, \mathrm{H}-16 \alpha), 4.96,4.91$ (each $1 \mathrm{H}, \mathrm{s}$ $\left.\mathrm{OCH}_{2} \mathrm{O}\right), 5.30(1 \mathrm{H}, \mathrm{s}, \mathrm{H}-6 \alpha)$.

Anthriscifolcine $\mathrm{G}(\mathbf{6})$ : White amorphous powder; $[\alpha]_{\mathrm{D}}^{20}-56.7^{\circ}(c=0.30$, $\left.\mathrm{CHCl}_{3}\right)$; IR (KBr) cm ${ }^{-1}: 3492,2929,1740,1244,1087 ;{ }^{1} \mathrm{H}-\mathrm{NMR}$ $\left(400 \mathrm{MHz}, \mathrm{CDCl}_{3}\right)$, see Table $1 ;{ }^{13} \mathrm{C}-\mathrm{NMR}\left(100 \mathrm{MHz}, \mathrm{CDCl}_{3}\right)$ see Table 2; HR-ESI-MS $m / z$ : $464.2650[\mathrm{M}+\mathrm{H}]^{+}$, Calcd for $\mathrm{C}_{25} \mathrm{H}_{38} \mathrm{NO}_{7}, 464.2648$.

Acetylation of Anthriscifolcine $\mathrm{G}(6): 0.5 \mathrm{ml}$ of acetic anhydride was added to a solution of anthriscifolcine $\mathrm{G}(6)(10 \mathrm{mg})$ in pyridine $(2 \mathrm{ml})$, and the mixture was stirred at room temperature for $4 \mathrm{~h}$. The usual work-up and flash column chromatography provided the acetylated analogue $\mathbf{6 a}(7 \mathrm{mg})$. 6a: white amorphous powder; $[\alpha]_{\mathrm{D}}^{20}-23.5^{\circ}\left(c=0.50, \mathrm{CHCl}_{3}\right) ;{ }^{1} \mathrm{H}-\mathrm{NMR}$ $\left(400 \mathrm{MHz}, \mathrm{CDCl}_{3}\right) \delta_{\mathrm{H}} 1.06(3 \mathrm{H}, \mathrm{t}, J=7.2 \mathrm{~Hz}, \mathrm{H}-22), 2.05,2.07$ (each $3 \mathrm{H}, \mathrm{s}$, $2 \times \mathrm{OAc}), 3.21(1 \mathrm{H}, \mathrm{s}, \mathrm{H}-17), 3.25,3.46\left(\right.$ each $\left.3 \mathrm{H}, \mathrm{s}, 2 \times \mathrm{OCH}_{3}\right), 3.69(1 \mathrm{H}, \mathrm{t}$ $J=4.8 \mathrm{~Hz}, \mathrm{H}-14 \beta), 4.78(1 \mathrm{H}, \mathrm{dd}, J=8.8,6.0 \mathrm{~Hz}, \mathrm{H}-16 \alpha), 4.77,4.75$ (each $\left.1 \mathrm{H}, \mathrm{s}, \mathrm{OCH}_{2} \mathrm{O}\right), 5.25(1 \mathrm{H}, \mathrm{s}, \mathrm{H}-6 \alpha)$.

Acknowledgment This research work was financially supported by the National Science Foundation of China (No. 30472075) and the Excellent Ph.D. Dissertation Foundation of China (No. 200367).

\section{References}

1) Zhou X. L., Chen D. L., Chen Q. H., Wang F. P., J. Nat. Prod., 68, 1076-1079 (2005).

2) Cai L., Chen D. L., Liu S. Y., Wang F. P., Chem. Pharm. Bull., 54, 779-781 (2006)

3) Gao F., Chen Q. H., Wang F. P., J. Nat. Prod., 70, 876-879 (2007).

4) Wang F. P., Yan L. P., Tetrahedron, 63, 1417-1420 (2007).

5) Wang W. C., Warnock M., "Flora of China," ed. by Wu Z. Y., Raven P., Hong D. Y., Science Press, Beijing, 2001, p. 273.

6) Song L., Liang X. X., Chen D. L., Jian X. X., Wang F. P., Chem. Pharm. Bull., 55, 918-921 (2007).

7) Pelletier S. W., Mody N. V., Joshi B. S., Schramm L. C., "The Alkaloids: Chemical and Perspectives," Vol. 2, ed. by Pelletier S. W., Wiley, New York, 1984, pp. 206-402.

8) Kulanthaivel P., Benn M., Heterocycles, 23, 2515-2520 (1985).

9) Ding L. S., Chen W. X., J. Nat. Prod. R\&D, 1, 6-32 (1989).

10) Pelletier S. W., Mody N. V., Dailer O. D. Jr., Can. J. Chem., 58, 18751879 (1980).

11) Ulubelen A., Desai H. K., Teng Q., Mericli A. H., Mericli F., Kolak U., Arfan M., Lee C. K., Pelletier S. W., Heterocycles, 51, 1897-1903 (1999).

12) Park J. C., Desai H. K., Pelletier S. W., J. Nat. Prod., 58, 291-295 (1995).

13) Chen Y. Z., Wu A. G., Phytochemistry, 29, 1016-1019 (1990). 